\title{
A VALLOMÁSOK IGAZSÁGTARTAMÁT MEGHAMISÍTÓK TÍPUSAI ÉS VIZSGÁLATUK KIHALLGATÁSI HELYZETBEN 4. rész, A patetikus
}

\author{
Madzin András ${ }^{1}$, Alpek Alex², Bártfai Anna ${ }^{3}$, Kertesy Andrea ${ }^{4}$, \\ Iványuk Áron ${ }^{5}$, Benczúr Lilla ${ }^{6}$, Takács Szabolcs ${ }^{7}$, Kis György ${ }^{8}$ \\ ${ }^{1}$ ANIMA Polygraph Kft, LVA szakértő, , \\ 2,3,4,5 Károli Gáspár Református Egyetem, Pszichológia Intézet, hallgató, \\ ${ }^{6}$ klinikai szakpszichológus, \\ 7 Károli Gáspár Református Egyetem, Pszichológia Intézet, egyetemi adjunktus, \\ ${ }^{8}$ ANIMA Polygraph Kft, Ügyvezető
}

\begin{abstract}
Absztrakt
Cikksorozatunkban annak a kutatómunkának az eredményiről számolunk be, amelyet 2014-ben kezdtünk annak reményében, hogy különböző hazugságot elkövető típusokat tudtuk sikerrel jellemezni (Kis et al., 2017).

Jelen cikkünkben a gyakorlatban legtöbbször előforduló helyzetet modelleztük: a hazugok nem „tiszta stratégiákat” alkalmaznak: egyszer elhallgatnak dolgokat, máskor megmásítják a történetet - vagy éppen nem füződik érdekük a hazugsághoz és igazat mondanak. Az utolsó típus megalkotásakor azt túztük ki célul, hogy a kevert stratégiák esetére is adaptálni tudjuk a módszerünket.
\end{abstract}

Kulcsszavak: hazugság • LVA • hangelemzés • tanúvallomás • kevert tipológiák • eltitkolás

A kutatási engedély száma 278/2016/P. A vizsgálatban résztvevő összes vizsgálati alany írásban hozzájárult a hanganyagok és videóanyagok további kutatásokban és tudományos publikációkban való felhasználásához.

\begin{abstract}
We report about the results of a research work in these series of articles, which we have launched in 2014 in the hope of successfully featuring different typologies of lies (Kis et al. 2017). In this article we model the most frequently occurring situations: the liars are not applying "clean strategies": in some cases they behave as an accomplice, in other cases they alter stories or they have no interest in lying so they tell the truth. When creating the last type we aimed to adapt our method in cases of mixed strategies.
\end{abstract}

Keywords: lie - LVA • speech analysis • deposition • secretive

Research license 278/2016/P. All participants signed a written document in which they declared: all audio and video records can be used for further researches and academic publications. 


\section{BEVEZETŐ}

A hazugságkutatók - bár többféle, olykor egymástól jelentősen eltérő megállapításokra jutnak - jórészt egyetértenek abban, hogy hazugságról akkor beszélhetünk, ha

- a hazugnak szándékában áll a megtévesztést elkövetni, tehát tudatosan igyekszik a valós tényektől eltérő információkat átadni a fogadó félnek;

- a hazug számára tétet jelent e szándék sikerre vitele: vagy valamilyen számára negatív következményt (pl. büntetést) kerül el vele, vagy pedig közvetlen nyeresége származik a megtévesztésből;

- a hazug tudja, hogy kockázatot vállal megtévesztő cselekedetével.

Kísérleteinkben három hazug típust (meghamisító, elhallgató, titkoló), valamint egy „státusváltó” típust (patetikus) vizsgáltunk. Jelen cikkünk a „státusváltó” típusra fókuszáló kísérleti eredményekről számol be.

A szakirodalom a patetikus típust, mint önálló tipológiát nem tárgyalja. Kutatásunkban ennek a tipológiának az elemzésére azért került sor, mert az LVA 6.50 hangelemző technológia a vizsgálatoknál elkülönített olyan érzelmi változókat, amely a kihallgatás közben lebuktatott hazug esetében volt jellemző. Az LVA technológia kihallgatásoknál történő alkalmazásával a nyomozónak olyan jelzéseket adott, ami a hazug bűntudatára (Fmain) és zavarodottságára (Fflic) mutatott. A folytatólagos kihallgatások esetében ezek a jelzések arra mutatnak, hogy a hazugnak erős bűntudata van, ami a hazugság egyik érzelmi forrása. Ezekkel a mutatókkal akár a kihallgatás során is operálni lehet, a hazug beismerő vallomását érhetjük el. Kísérletünk során is ezt a módszert alkalmaztuk. A kiválasztott maffiatagot néhány kérdésre adott válasz után lebuktattuk, szembesítettük azzal, hogy maffiatag ${ }^{1}$. Fontos megjegyezni, hogy a játék során a leleplezett elkövetők már túl vannak egy sikeres együttmúködésen - társaikkal egy játékostársukat mindenképpen sikeresen kiiktatták.

A kutatási összefoglalóban (Kis et al., 2017) részletesen bemutattuk a maffiajátékot, valamint annak szerepeit. A patetikus megnevezés megtévesztő lehet: a kísérlet során megfigyelt reakció leírására használtuk. A kísérleti helyzetben ugyanis a lebuktatott maffiatagok (lebuktatott meghamisítók, elkövetők) esetében azt figyeltük meg, hogy a lebukás pillanatában az elveszített játék miatti kedvetlenség volt tetten érhető.

Kísérleti szempontból azonban e típusnak sokkal fontosabb szerep jutott annak gyakorlati jelentősége miatt. A kihallgatási helyzetekben, vallomásokban az a tény, hogy a hazugság tétje teljesen kikerüljön a helyzetből, lényegében elképzelhetetlen. Ha másra nem is, a büntetési tételben való alkudozásnak min-

$1 \quad$ Miután az egész elemzés konzervált, utóelemzések segítségével történik, ezért itt nem az LVA eredményei alapján buktattuk le a maffiatagot, hanem a játékvezetők jelzése alapján előre eldöntöttük, hogy melyik játékos fog lebukni. 
denképpen lesz tétje a hazug számára. Ezzel szemben kísérletünkben a tét kikerült a rendszerből (megbukott a maffiatag, ő már nem nyerhetett). Azonban azt ki kell itt emelnünk, hogy e vizsgálati alanyok esetében nem homogén hangmintákról volt szó, hanem a lebuktatásig a meghamisító, utána pedig egyfajta kontrollként szolgáló, „tét nélküli” helyzetben vallomást tevő hanganyagát vizsgálhattuk. Így esetükben a kevert típusok vizsgálatának módszertani helyzeteit tudtuk vizsgálni - mely módszertannak viszont óriási jelentősége van a gyakorlati felhasználhatóság szempontjából.

Egy gyakorlati példával élve: a nyomozóhatóság betöréses lopás ügyében nyomozott, amit egy cég sérelmére követtek el. A helyszíni szemle és az azt követő szakértői vélemények arra mutattak, hogy a kérdéses páncélszekrényt egy másolt kulccsal nyitották ki. Megállapítást nyert, hogy a cég telephelyén a betörés időpontjában az utcai ajtó nem volt bezárva. A riasztó és a kamera rendszer már néhány napja a betörést megelózően nem múködött. A nyomozók verziója az volt, hogy belső ember lehetett a tettes, vagy adott tippet az elkövetőnek. Mindenképpen olyan személy, aki birtokában volt annak az információnak, hogy adott időben mennyi pénz volt a páncélszekrényben és milyen módon lehet bejutni az egyébként zárt épületbe. Az elkövetést éjjel hajtották végre. A nyomozóhatóság több dolgozót is kihallgatott. Két személyt meggyanúsítottak azzal, hogy a betöréses lopásban érintettek. Mindkét személy esetében poligráf vizsgálatot végeztek, de a gyanúsítottak a büncselekményt nem ismerték el. Ezt követően LVA 6.50 hangelemző technológia felhasználásával vizsgálták a gyanúsítottakat, annak érdekében, hogy a nyomozóhatóság több információhoz jusson. Az egyik gyanúsított drogfüggő volt, a kihallgatása előtti éjjelen is kábítószert használt. Az LVA kimutatta a kábítószerhasználatból eredő kritikus mentális állapotot (AVJ), ${ }^{2}$ de emellett a zavarodottságot (Fflic) és a büntudatot (Fmain) is. Az érintettségére feltett kérdéseknél magas értéket regisztrált az LVA a hazugság stressz és a hazugság valószínűsége esetében. Magas volt továbbá a globális stressz mutatója, ami a negatív izgatottságot, félelmet jelöli. A nyomozók úgy döntöttek, hogy vallomásra bírják a gyanúsítottat, aki beismerő vallomást tett. A kihallgatás folytatódott és az LVA mutatóinak elemzésénél azt tapasztalták, hogy a magas kockázati értékek eltűntek, nem voltak a lebukástól való félelemre mutató jelzések, a globális stressz sem mutatott továbbra magas értékeket. Kiderült, hogy a gyanúsított szervezte meg a kulcs másolását úgy, hogy azt egy munkatársának - a másik gyanúsítottnak - adta át, aki lemásoltatta a kulcsot. A betöréshez tippet adott és az elkövetőknek lehetővé tette az épületbe való bejutást. A kihallgatáson kiderült, hogy a gyanúsított a sértett tulajdonosi körtől nagyon félt, mert megbíztak benne, és attól tartott, hogy megölik, ha kiderül az ő érintettsége a büncselekményben. Jobbnak látta megtenni a vallomást a nyomozóhatóságnak. Motivációja a pénzszerzés volt, hogy kábítószerfüggőségét finanszírozni tudja.

A büneset ismertetésének legnagyobb tanulsága, hogy a leleplezéstől való

AVJ: LVA paraméter a kritikus mentális állapot jelzésére. 
félelem - mint az egyik legjobban tetten érhető hazugságra mutató érzelmi jel - jól detektálható nemcsak a mikrokifejezések szintjén, ahogy azt Ekman több esetben (1997, 2009; Ekman, Sullivan, \& Frank, 1999) is leírta, hanem a paraverbális (hang jellegzetességei) csatornán is. Az LVA jelzéseket ad abban az esetben, ha a hazug zavarodott és erős bűntudata van. Ezeket a jelzéseket értékelve a hazugot le lehet buktatni, várhatóan beismerő vallomást fog tenni. A beismerő vallomás valódiságát pedig ellenőrizni lehet az LVA paraméterekkel. Tapasztalhatjuk, hogy a vallomás első részében a hazug a meghamisító jelzéseit adja, majd a beismerő vallomást követően a meghamisítóra mutató tipológiai ismérvek megszünnek.

\section{A LELEPLEZETT ELKÖVETŐK: „A PATETIKUSAK”}

Cikkünk a patetikusak csoportjára, mint kevert tipológiára fókuszál. A kísérletnél használt játékban, a „maffia játékban” (Kis et al., 2017) a patetikus az a személy, akit a kihallgatás során a kihallgatás elején, az első néhány kérdés után lebuktatunk. Ez úgy történik, hogy a kísérlet során a lebuktatandó játékost bekísérő személy titokban jelez a kihallgatónak, hogy a játékost le lehet buktatni (így különítettük el őket a le nem bukott elkövetők csoportjától). Lényegében a „kihallgatás” során már az első kérdésekre adott válaszok után a kihallgató közli a játékossal a lebukás tényét, aki ezután ebben a tudatban vesz részt a kihallgatás további részén.

\section{KAPCSOLAT A TÖBBI TÍPUSSAL}

Ahhoz, hogy a patetikust megértsük, szükséges ismernünk a hazugságok lehetséges okait, illetve a hazugság fiziológiai hátterét. Ezekről pontosabban az öszszefoglaló tanulmányban olvashatunk, illetve találhatunk további forrásokat (Kis et al., 2017).

A patetikus, kevert típus esetében ezt egy előre meghatározott, jól látható vizsgálati pont beiktatásával értük el: a kihallgatást végző szakember egy előre meghatározott időpontban (előre meghatározott kérdésre adott válasz közben) szembesítette a vizsgálati alanyt, így pontosan tudtuk, hogy mely hanganyagok kerülnek a meghamisító és mely hanganyagok a lebuktatás utáni elemzési csoportba. Tehát e kevert kategória esetében a heterogén hanganyagot két, homogén részre vághattuk. 


\section{A LELEPLEZETT ELKÖVETÓ JELLEMZÉSE A HANGELEMZÉS SEGÍTSÉGÉVEL - A KÍSÉRLET EREDMÉNYEINEK BEMUTATÁSA}

Vizsgálatunkban azt igyekszünk bemutatni, hogy valóban ez a helyzet áll fenn: a patetikus, leleplezett elkövetők - az eddigiekben már bemutatott típusoktól eltérően - hangjában nem találunk érzelmi jellegzetességeket a lebuktatás utáni szegmensekben. Lényegében a kontroll csoportként szolgáló alanyok értékeihez hasonló eredményeket fognak szinte minden esetben mutatni. Az LVA alkalmazásánál a lebuktatást követő kihallgatás során már nem tapasztalunk olyan kognitív és érzelmi reakciókat, amelyek megtévesztés szándékára mutatnának.

Az elemzés matematikai hátterét itt is egy másik, szintén e folyóirat hasábjain megjelenő dolgozatunkban mutatjuk be (Takács et al., 2017, illetve Kis et al., 2017a). Az eljárás gyors ismertetése: „Az eredmények matematikai feldolgozásának alapját lásd Takács és társai (2017) cikkében, így erre külön nem térünk ki. A típusok összehasonlítására egy bootstrap eljárással kombinált varianciaanalízist alkalmaztunk (a bootstrap eljárást más pszichológiai vizsgálatokban is sikeresen lehet alkalmazni, lásd Marcinko et al., 2013). Bár az LVA paraméterekre a normalitás nem teljesült (Kolmogorov-Smirnov tesztet alkalmazva

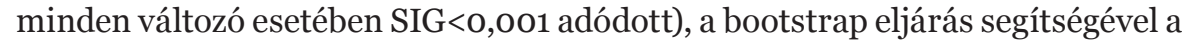
csoportok közvetlen hibáját határoztuk meg - így a csoportok összehasonlíthatókká váltak egymással (Efron \& Gong, 1983). A bootstrap eljáráshoz IBM SPSS 23.o programcsomagot használtunk.

A normalitás hiánya miatt a varianciaanalízist rangvarianciaanalízis alkalmazásával is ellenőriztük (Kruskal-Wallis teszttel, illetve rang-Welch-próbával), a páros összehasonlításokhoz pedig Bonferroni korrekcióval elvégzett BrunnerMunzel (BM) tesztet használtunk. A sztochasztikus homogenitás-vizsgálatokhoz (lásd Vargha, 2005) a ROPstat programcsomagot alkalmaztuk.

A patetikus tipológia esetében tehát azt fogjuk tapasztalni, hogy a lebuktatás után, a tét megszűnése miatt nem fogunk érdemben szignifikáns eltéréseket megfigyelni.

Az előzetesen elmondottakhoz híven mindösszesen 3 ponton látunk szignifikáns eltérést a többi, kihallgatott vizsgálati alany értékeihez képest - és mindhárom esetben azoknál alacsonyabb értékeket mutatnak a patetikusok.

Megfigyelhető, hogy esetükben a leginkább egyenletes a beszéd (nincsenek a hangszínben, hangerősségben nagyobb megingások), a gondolkodási arány kifejezetten alacsony a többi megkérdezetthez képest, valamint az elfojtott érzelmi szint is szignifikánsan alacsony értéket mutat.

Mindezt az alábbi módon tudjuk interpretálni: a problémát elengedte, lényegében „mesél” számunkra. Nincsenek tétek, nincsen érzelmi érintettség. Ami még ennél is érdekesebb talán: a kihallgatás okozta izgalom - mely például a kontroll csoportnál tetten érhető lehet (tehát annak egy alap szintje) - is megszűnik! Alacsonyabb ugyanis az elfojtott érzelmi szint, nem kell gondolkodnia azon, mit mond - és kiegyensúlyozottabb, kiegyenlítettebb a beszéde, a hangja a vizsgálati személyeknek. 
A VALLOMÁSOK IGAZSÁGTARTAMÁT MEGHAMISÍTÓK TÍPUSAI ÉS VIZSGÁLATUK... 4. RÉSZ

\section{1. táblázat}

Tipológiai sajátosságok - sztochasztikus dominancia mértéke az egyes paraméterek mentén

\begin{tabular}{lccccc}
\hline & Dominancia & BM & szabadsági fok & $\mathbf{p}$ & korrigált p \\
\hline Érzelmi szint & 0,476 & $-1,74$ & 1464,1 & 0,0829 & 0,4145 \\
Kognitív szint & 0,514 & 0,97 & 1187 & 0,3333 & 1 \\
Stressz szint & 0,474 & $-1,86$ & 1451,2 & 0,0627 & 0,3133 \\
Gondolkodási szint & 0,508 & 0,56 & 1740,7 & 0,573 & 1 \\
Közlési hajlandóság hiánya & 0,484 & $-1,15$ & 1171,6 & 0,2488 & 1 \\
Koncentráció & 0,521 & 1,38 & 967,7 & 0,1666 & 0,8332 \\
Párhuzamos gondolatok & 0,492 & $-0,58$ & 1040,1 & 0,5605 & 1 \\
Egyenletesség & 0,454 & $-3,3$ & 1301,9 & 0,001 & $0,0050^{* *}$ \\
Zavarodottság & 0,47 & $-2,04$ & 1039,3 & 0,0417 & 0,2085 \\
Hazugság stressz & 0,504 & 0,3 & 1295,8 & 0,7669 & 1 \\
Hazugság valószínúség & 0,486 & -1 & 1220,6 & 0,3175 & 1 \\
Kognitív szint & 0,467 & $-2,34$ & 1261,7 & 0,0195 & $0,0973+$ \\
Globális stressz & 0,472 & $-2,02$ & 1433,9 & 0,0437 & 0,2187 \\
Téma elutasítottsága & 0,485 & $-1,02$ & 1024,3 & 0,308 & 1 \\
Reakcióra való várakozás & 0,494 & $-0,38$ & 1047 & 0,7055 & 1 \\
Gondolkodási arány & 0,461 & $-2,7$ & 1181,8 & 0,0071 & $0,0354^{*}$ \\
Tudat alatti megismerési szint & 0,476 & $-1,72$ & 1351,9 & 0,0853 & 0,4264 \\
Elfojtott érzelmi szint & 0,429 & $-4,96$ & 1103,3 & 0 & $0,0000^{* * *}$ \\
\hline Képzelet, fantázia & 0,5 & $-0,03$ & 1537,7 & 0,9756 & 1 \\
\hline
\end{tabular}

\section{DISZKUSSZIÓ}

A bünüldözés során cikkünk vizsgálatának alapesetei lényegében bármikor adódhatnak: a kevert típusok igen gyakran előfordulhatnak. A kihallgatás során egyes kérdésekben a válaszadó őszintén válaszol, más esetekben esetleg elhallgat információkat, míg megint más szituációkban, kérdésekben a meghamisítás eszközét választja. Ekkor az a cél, hogy egymástól szeparálni tudjuk ezeket a területeket a hanganyagban - majd utána a szeparált területeket külön-külön értékeljük.

A beismerő vallomás elérése a bűntudattal van összefüggésben. A hazug zavarodottságot érez, nem tudja mitévő legyen, elmondja-e az igazságot, vagy to- 
vábbra is tagadjon. Az LVA adott paraméterei (Fmain, Fx, Fflic) segítik a kihallgatót abban, hogy vallomásra bírja a hazugot. Ehhez a kihallgatónak jól kell megválasztani az időpontot, motiválni kell a hazugot, hatni kell az érzelmeire. Ha eldönti a hazug, hogy beismerő vallomást tesz és azt meg is kezdi, onnantól fokozatosan megszúnik a stressz, a lebukástól való félelem és nem fog hazugságjelzéseket mutatni. Belefárad a korábbi meghamisításban, arousal szintje lecsökken, ami magyarázhatja azt, hogy a kontroll csoportnál is alacsonyabb értékeket kapunk az LVA visszajelzései szerint.

Eredményeink kapcsán elmondható, hogy a hazugság egyik kulcs momentuma a tét (Ekman, 2009; Biland, 2009). Azonban: ha a tétnek már nincs jelentôsége, a vizsgálat során megszünik a hazugság elkövetésére irányuló motiváció, úgy a szivárgások és a hazugság jelzések intenzitása is lecsökken. Figyeljünk azonban arra, hogy a gyakorlatban a tét lényegében sosem szűnik meg! Egy kihallgatás során egy bünelkövető előtt mindig ott lebeghet a büntetési tétel csökkentésének lehetősége, így a valós helyzetekben igen ritkán fordulhat elő az a vegytiszta, tétnélküli helyzet elérése, ami természetesen e kísérleti helyzetben megvalósult.

Ennél azonban gyakorlatiasabb eredménye e típus vizsgálatának az, hogy igazoltuk: kevert típusok esetében is tudunk elemzéseket végezni a vizsgálati eszközeinkkel akkor, ha a vizsgálatot folytató személy, a kihallgatást végző szakember el tudja különíteni a különböző kérdésekre adott válaszokat, illetve kisebb részmintákra tudja szedni a hanganyagokat. Így egy-egy vallomás - bár eredetileg heterogén, kevert típussal rendelkeztünk, rövidebb homogén részekként értékelhetők.

\section{KITEKINTÉS, ÖSSZEGZÉS}

Összességében az alábbi eredmények mondhatók el a patetikus típus esetében: A patetikusok úgy kerülnek be egy kihallgatási helyzetbe, hogy elkövetők lévén titkolni kell kilétüket, tetteiket - és ezt a történet megmásításával igyekeznének elérni. A kihallgatás kezdetekor - tudva azt az 1. részben tárgyalt (Czabán et al., 2017a) meghamisító típus jellemzéséből - jellemezhető egyfajta felfokozott, a megtévesztés örömével is bíró állapottal.

Ezt az állapotot a lebuktatással megszüntettük és egyértelmúvé tettük: tudjuk, mit tett, lelepleződött. Nagyon fontos azonban azt megjegyeznünk, hogy a valós, éles helyzetekben ez igen ritkán fordulhat elő. A kísérletünknek ezen a ponton nem is a valós helyzet szimulálása volt a célja, hiszen ezt, a „tét csökkentését” egy ilyen kísérleti helyzetben nem tudtuk előidézni. Ugyanakkor a típusok keveredése valós problémát jelent a kihallgatásoknál. A célunk ez esetben az volt, hogy a kevert tipológiákhoz tartozó módszertani eljárásunkat tesztelni tudjuk - és egy előre meghatározott ponton tudjuk a típusok keveredését elér- 
ni. Erre a patetikus tipológia kialakítása megfelelőnek bizonyult. Ezzel a vizsgálati módszertannal az is igazolhatóvá vált, hogy ha ilyen helyzetekben a szakember kellő körültekintéssel a kevert anyagokat kisebb, homogén részekre tudja bontani, sikeresen alkalmazhatjuk a kidolgozott módszertanunkat a rövidebb részletek azonosítására.

\section{BIBLIOGRÁFIA}

Biland, C. (2009). A hazugság pszichológiája. Budapest: Háttér Kiadó.

Efron, B., \& Gong, G. (1983): A Leisurely Look at the Bootstrap, the Jackknife, and Cross-Validation,

The American Statistician, Vol. 37 (1), 36-48.

Ekman, P. (2009). Beszédes hazugságok: A megtévesztés árulkodó jelei a politikában, az üzletben és a házasságban. Budapest: Kelly Kft. (Eredeti: Ekman, P.: Telling Lies. Fordította: Andersen Dávid) Ekman, P. (1997). Deception, lying and demeanor. Oxford: Oxford University Press.

Ekman, P, Sullivan, M.O., \& Frank, M.G. (1999). A few can catch a liar. Research report. Psychological Science, $10,(3) .263-266$.

Marcinko, D., Jaksic, N., Ivezic, E., Skocic, M., Surányi, Zs., Loncar, M., Francic, T., Jakovljevic, M. (2013): Pathological Narcissism and Depressive Symptoms in Psychiatric Outpatients: Mediating Role of Dysfunctional Attitudes, Journal of Clinical Psychology, 70(4), 341-352.

Vargha András (2005). Sokaságok összehasonlítása új módszerekkel, Statisztikai Szemle 83, 429-448.

\section{Tematikus szám hivatkozott cikkei}

Kis, Gy., Takács, Sz., Liberman, A., \& Benczúr, L. (2017). A megtévesztés tipológiája - összefoglaló tanulmány. Psychologia Hungarica Caroliensis, 4(2), 2016. pp. 7-26.

Czabán, Cs., Alpek, A., Bártfai, A., Kertesy, A., Iványuk, Á., Benczúr, L., Takács, Sz., \& Kis, Gy. (2017a). A vallomások igazságtartamát meghamisítók típusai és vizsgálatuk kihallgatási helyzetben -1 . rész, a meghamisító. Psychologia Hungarica Caroliensis, 4(2), 2016. pp. 27-35.

Takács, Sz., Kis, Gy., Makrai, B., Liberman, A. (2017). Tipológiákhoz tartozás varianciaanalízis alkalmazásával, LVA hangelemzés vertikális vizsgálata. Psychologia Hungarica Caroliensis, 4(2), 2016. pp. 79-93. 